\title{
Correction: assessment of bacterial diversity during composting of agricultural byproducts
}

\author{
Piyush Chandna ${ }^{1}$, Lata Nain², Surender Singh ${ }^{2}$ and Ramesh Chander Kuhad ${ }^{1 *}$
}

\section{Correction}

After the publication of this work [1], we found that Table 4 is a duplication of Table 2 in our related publication [2] and some of the text within the methods section is also duplicated. We have now obtained permission to reuse this material with kind permission from Springer Science + Business Media: Applied Microbiology and Biotechnology (2013) 97 (15) p 6991-7003. Piyush Chandna, Sarita Mallik and Ramesh Chander Kuhad. Table 2. @Springer-Verlag Berlin Heidelberg 2012.

We apologize for the inconvenience that this may have caused.

\section{Author details}

'Lignocellulose Biotechnology Laboratory, Department of Microbiology, University of Delhi South Campus, Benito Juarez Road, New Delhi 110 021, India. ${ }^{2}$ Division of Microbiology, Indian Agricultural Research Institute, New Delhi 110 012, India.

Received: 9 December 2013 Accepted: 3 February 2014

Published: 11 February 2014

\section{References}

1. Chandna P, Nain L, Singh S, Kuhad RC: Assessment of bacterial diversity during composting of agricultural residues. BMC Microbiol 2013, 13:99. 10.1186/1471-2180.

2. Chandna P, Mallik S, Kuhad RC: Assessment of bacterial diversity in agricultural by-product compost by sequencing of cultivated isolates and amplified rDNA restriction analysis. Appl Microbiol Biotechnol 2013, 97:6991-7003. 